Brit. F. industr. Med., 1966, 23, 318

\title{
Acute Intoxication from Antimony Trichloride
}

\author{
P. J. TAYLOR \\ From Shell Refining Company Limited, Shell Centre, London, S.E.I
}

Seven men were accidentally exposed to the fume of antimony trichloride. Their symptoms included not only the well-recognized upper respiratory irritation from hydrochloric acid but, in five of the men, an additional, slightly delayed onset of gastro-intestinal disturbance including abdominal pain and persistent anorexia. Urine antimony estimations revealed a concentration in excess of $\mathrm{I} \mathrm{mg}$./litre in these five men. Environmental measurements suggest that they were briefly exposed to air containing up to $146 \mathrm{mg}$. hydrochloric acid and $73 \mathrm{mg}$. antimony per $\mathrm{m}^{3}$ expressed as the metal. These findings are compared with other reports on chronic antimony intoxication. No report could be found in recent literature about acute intoxication from antimony trichloride.

Antimony and its compounds are relatively uncommon as causes of industrial disease. Most reports of industrial antimony intoxication refer to chronic exposure in the smelting and refining of the ores in which disorders of the stomach and intestines, lungs, heart, and skin have been reported (Renes, 1953; Browning, 196r; McCallum, 1963). The compounds of antimony most frequently found in industry are alloys with lead, tin, and copper and the tri- and pentavalent oxides and sulphides. Another compound, antimony trichloride, has an industrial application in the treatment of brass, textile dyeing, and various specific processes in the chemical industry. The current threshold limit value is $0.5 \mathrm{mg} . / \mathrm{m}^{3}$ air, expressed as antimony.

This paper describes acute intoxication in seven men after exposure to fumes containing antimony trichloride. All seven absorbed significant amounts of antimony and five suffered symptoms of gastrointestinal origin referable to the known systemic action of the metal. Safety data reports have been primarily concerned with the acid hazard, not with a risk of systemic intoxication (Manufacturing Chemists' Association, 1957), and no record can be found in recent literature of such an occurrence.

\section{Source of the Antimony Fume}

Antimony trichloride $\left(\mathrm{SbCl}_{3}\right)$ is used in an enclosed process in which it is circulated at a high temperature (about $100^{\circ} \mathrm{C}$.) and pressure (about roo-200 lb./sq. in.) as a $98 \%$ solution in anhydrous

Received for publication April 4, 1966. hydrochloric acid $(\mathrm{HCl})$. Such a corrosive mixture produced leaks in the two nickel alloy reciprocating pumps from time to time.

The danger of the $\mathrm{HCl}$ vapour was fully appreciated, and complete protective clothing in the form of neoprene suits, boots, gloves, and plastic eye shields or air-line helmets was provided for any man working in contact with the catalyst.

\section{Description of Exposures}

Two pairs of men (cases I to 4) were exposed for brief periods while working eight-hour shifts on leaking pumps. Despite the supply of full protective clothing they had removed their air-line helmets from time to time during work because the helmets were awkward to work in and because they felt that they could tolerate some $\mathrm{HCl}$ vapour.

Three men were exposed when one of them (case 5) was removing an instrument from an incompletely closed line without wearing any protective clothing. Two other men wearing the clothing but no respirators went to his assistance when the sudden leak occurred. One of them (case 6) removed his eye shield but both he and case 5 were only briefly exposed to the fume; the third man (case 7) was exposed for a little longer. While the first four men were exposed mostly to fume, the second episode exposed the men to both fume and spray.

\section{Clinical Observations}

Burns were treated immediately with free and 
copious irrigation with water and then with magnesium oxide cream. All the men were examined by the author as soon as their condition was known but in the first two men this was not until the day after the incident since they did not report their sickness. They were traced when the second pair of men had reported to the medical centre at the end of their shift.

Case I A maintenance fitter aged 29 suffered soreness of the upper respiratory tract while working and about eight hours later developed nausea, anorexia, and a mild intermittent central abdominal pain. On the second day all respiratory soreness had gone but the abdominal pain remained until the third day and normal appetite did not return until the fifth day. On examination (second day) there were no abnormal physical signs and no abdominal tenderness.

Case 2 A fitter's mate aged 26 suffered soreness of the upper respiratory tract while working and some nausea at the end of the shift. On the second day all respiratory symptoms had cleared but he noticed slight central abdominal pain and loss of appetite. The pain lasted for one day but normal appetite did not return until the fourth day. On examination (second day) he was found to have a very small acid burn on the right wrist but no other physical signs.

Case 3 A maintenance fitter aged 25 reported to the medical centre at the end of his working shift with soreness of the upper respiratory tract and slight nausea. About four hours later he vomited once and developed a dull constant central abdominal pain, anorexia, and a frontal headache. On the second day all respiratory symptoms and the headache had cleared, and the abdominal pain slowly improved and had gone by the fifth day. His normal appetite did not return until the tenth day. He stayed away from work for three days. On examination on the first day there was slight nasopharyngeal erythema but no other physical signs, and on subsequent days no abnormal physical signs could be found.

Case 4 A fitter's mate aged 28 reported to the medical centre at the end of his working shift with soreness of the upper respiratory tract and nausea. About two hours later he vomited twice and developed intermittent central abdominal pain. On the second day the respiratory symptoms had gone and the abdominal pain was less severe and had become constant. He also had headache and anorexia. The headache lasted for one day and the abdominal pain had gone by the fourth day. His normal appetite returned on the eighth day. He stayed away from work for six days. Physical examination on the first day showed only some nasopharyngeal erythema, and no physical signs were found on subsequent days.

Case 5 A maintenance fitter aged 52 sustained acid vapour burns of first and second degree around both eyes with moderate oedema of the lids and conjunctivae but no corneal involvement. He also had a second degree burn about $2 \times I$ in. $(50 \times 25 \mathrm{~mm}$.) by the left clavicle. His nose and throat felt sore for a few hours only and at no time did he have any abdominal symptoms. He was away from work for four days, the facial burns healing in three days and the chest burn in Io days. Apart from the burns he had no abnormal physical signs.

Case 6 An operator aged 26 sustained acid burns of first and second degree around both eyes with considerable oedema of the lids and conjunctivae and a small superficial ulcer on the left cornea. He also had upper respiratory tract soreness for a few hours but no other symptoms. The corneal ulcer cleared completely in three days and the eyelid burns in ro days. He was away from work for Io days. Apart from the burns he had no other physical signs.

Case 7 An operator aged 35 sustained several small splash burns around the ears and neck. After the initial upper respiratory soreness had passed off he felt well (apart from burn pain) until the second day when he vomited once and for that day only had no appetite. The burns were all healed by the tenth day when he returned to work. Apart from the burns he had no other physical signs and when seen on the second day there was no abdominal tenderness.

The main symptoms experienced by these seven men are presented in Table I. All of them had transient irritation of the upper respiratory tract which was probably caused by the $\mathrm{HCl}$ vapour, but five of them also had delayed symptoms arising from the gastro-intestinal tract.

\section{TABLE I}

\section{Symptoms Experienced by the Seven MEN}

\begin{tabular}{|c|c|c|c|c|c|c|c|}
\hline \multirow[t]{2}{*}{ Symptom } & \multicolumn{7}{|c|}{ Case Number } \\
\hline & $\mathbf{I}$ & 2 & 3 & 4 & 5 & 6 & 7 \\
\hline Acid burn & - & + & - & - & + & + & + \\
\hline Soreness of upper resp. tract & + & + & + & + & + & + & + \\
\hline Nausea & + & + & + & + & - & - & - \\
\hline Abdominal pain & + & + & + & + & - & - & - \\
\hline Vomiting & - & - & + & + & - & - & + \\
\hline Anorexia & + & + & + & + & - & - & + \\
\hline Headache & - & - & + & + & - & - & - \\
\hline
\end{tabular}

Other symptoms and physical signs which have been reported by some authors, such as dyspnoea, diarrhoea, nasal ulceration, cardiac rhythm irregularities, and urinary symptoms, were not present in any of these cases.

Routine blood counts including haemoglobin estimation and white cell count were normal in cases I to 4 , and a chest radiograph of each man was normal. 


\section{Antimony Levels in Urine}

When the first incident occurred the local laboratory could not undertake urine antimony measurement and the specimens were sent for analysis to the Occupational Hygiene Service of the Nuffield Department of Occupational Health at Manchester University. Subsequently the analyses were done locally using the same technique of wet oxidation and polarographic measurement.

Each specimen consisted of at least $100 \mathrm{ml}$. urine, having a specific gravity of not less than I.OIO. With the exception of the first specimens from cases 5 to 7 , which were collected three hours after exposure, all urine specimens were taken on waking from sleep.

The results are presented in Table II. Unfortunately only three specimens were obtained from the four men involved in the first incident and at intervals of several days.

These results show a rapid fall in urine antimony content and suggest that urinary excretion is relatively quick. Each specimen was examined for protein and formed elements but none was found.

At the time of the second incident, urine antimony estimations had become a regular procedure for screening purposes, and the first specimens were collected three hours after exposure, and subsequent ones each day.

\section{Environmental Investigations}

Regular monitoring of air samples from various parts of the process have been undertaken during conditions ranging from normal leak-free operation (when the $\mathrm{HCl}$ level varies from o to $5.5 \mathrm{mg} . / \mathrm{m}^{3}$ and the antimony from 0 to $0.4 \mathrm{mg} . / \mathrm{m}^{3}$ ) to occasions when a pump was leaking when $\mathrm{HCl}$ levels as high as $45 \mathrm{mg} . / \mathrm{m}^{3}$ and antimony at $49 \mathrm{mg} . / \mathrm{m} .{ }^{3}$ were recorded. The method of sampling was to draw ro litres of air in through $\frac{1}{4}$ in. $(6 \cdot 3 \mathrm{~mm}$.) glass tube passing through two bubbler bottles, each containing $50 \mathrm{ml}$. water and $10 \mathrm{ml}$. $\mathrm{N} /$ Io sodium hydroxide. The rate of sampling was approximately I litre per minute, the air being drawn into an evacuated graduated bottle with a manometer. Estimation of the antimony was undertaken by the modified Gutzeit method, and as antimony trichloride is very water soluble no antimony was found in the second bubbler even when the concentrations were high.

In order to assess the sort of fume which could have been inhaled during both incidents, air samples were taken $3 \mathrm{ft}$. $(91 \mathrm{~cm}$.) down wind from a leaking pump. The antimony content was found to be $73 \mathrm{mg} . / \mathrm{m}^{3}$ and the $\mathrm{HCl}$ was $146 \mathrm{mg} . / \mathrm{m}^{3}$. Watchglasses were placed at varying distances from the source for Io minutes, and the antimony deposit was then measured. At $6 \mathrm{ft}$. ( $1 \cdot 8 \mathrm{~m}$.) from the source there was II.2I $\mu \mathrm{g}$. Sb/cm. ${ }^{2}$, at $\mathrm{I} 4 \mathrm{ft}$. $(4 \cdot 2 \mathrm{~m}$.) the concentration was $2 \cdot 19 \mu \mathrm{g} . / \mathrm{cm}^{2}$, and at $25 \mathrm{ft}$. $\left(7.6 \mathrm{~m}\right.$.) $0.52 \mu \mathrm{g} . / \mathrm{cm}{ }^{2}$. All antimony concentrations are expressed as the metal and not as the trichloride.

\section{Special Survey of Workers}

Twenty-two men were examined and the urine antimony content was measured at a time when none of them had been in any contact with the compound for at least four weeks. All were clinically healthy, one had $0.0004 \mathrm{mg}$. antimony/litre urine and the others had none at all. Ten weeks later when the process was working normally 19 of them were re-examined. All were clinically healthy and only two had small amounts of antimony in the urine $(0.20 \mathrm{mg}$. and $0.31 \mathrm{mg}$./litre). The man who had a trace in the previous survey had none on this occasion. Five of the seven men involved in the episodes described above had no antimony on either occasion, the other two were not seen.

\section{Other Exposures}

Three men have been involved in the inhalation of small quantities of the fume on two other

TABLE II

Urine Antimony Content (MG./Litre)

\begin{tabular}{|c|c|c|c|c|c|c|c|c|}
\hline \multirow{2}{*}{$\begin{array}{l}\text { Case } \\
\text { No. }\end{array}$} & \multicolumn{8}{|c|}{ Days after Exposure } \\
\hline & 3 hrs. & $\mathbf{I}$ & 2 & 3 & 4 & 7 & 8 & 21 \\
\hline I & - & - & $5 \cdot 10$ & - & - & - & 0.01 & Nil \\
\hline 2 & - & - & 1.00 & - & - & - & 0.02 & Nil \\
\hline 3 & - & * & - & - & - & 0.02 & - & Nil \\
\hline 4 & - & $I \cdot 10$ & - & - & - & 0.02 & - & Nil \\
\hline & 0.36 & Nil & Nil & Nil & - & - & - & - \\
\hline 6 & $<0.05$ & $1 \cdot 50$ & Nil & Nil & - & - & - & - \\
\hline 7 & $<0.05$ & $2 \cdot 30$ & $<0.05$ & Nil & - & - & - & - \\
\hline
\end{tabular}

^Sample bottle broken in transit 
occasions. In no case did they have more than upper respiratory irritation for a few hours, and in particular no gastro-intestinal symptoms. Urine specimens collected from two of the men at the time of symptoms were found to contain $0.909 \mathrm{mg}$. and $0.853 \mathrm{mg}$. respectively per litre; the third man had no antimony in his urine. On each occasion urine specimens taken 24 hours later contained no antimony.

\section{Discussion and Conclusions}

As is often the case when an investigation of acute accidental exposure is reported, the results of this paper leave many questions unanswered. It is not possible to assess the exact exposure experienced by the men; practical considerations made 24-hour urine collection impossible, and faecal excretion was not measured.

Nevertheless the present investigation has shown that inhalation, for brief periods, of fume containing up to $146 \mathrm{mg}$. $\mathrm{HCl}$ and $73 \mathrm{mg}$. antimony $/ \mathrm{m}^{3}$ can produce not only the well-recognized upper respiratory irritation of $\mathrm{HCl}$ intoxication but also a slightly delayed onset of gastro-intestinal symptoms. These latter symptoms, in which loss of appetite was most pronounced, are attributed to the systemic action of antimony. In such cases the urine antimony content has been shown to exceed $\mathrm{I} \cdot 0 \mathrm{mg}$. /litre.

The air levels of antimony reported here are considerably higher than those mentioned by other investigators (Renes, 1953; Brieger, Semisch, Stasney, and Piatnek, 1954; McCallum, 1963) but all these authors were describing persistent conditions. Similarly, the urine antimony content was also higher than has been reported in cases of chronic intoxication where levels in the order of 0.4 to $0.7 \mathrm{mg}$./litre (McCallum, 1963) and 0.03 to $0.2 \mathrm{mg}$. /litre (Gallina and Luvoni, 1958) have been described.

The observation that the urine antimony levels fell very rapidly is important and contrasts with the findings of McCallum (1963). He was studying smelters of antimony oxide and showed that a furnace worker had $0.055 \mathrm{mg}$./litre some months after leaving the work and $0.028 \mathrm{mg}$./litre four years later. The explanation of this may lie in the form in which the antimony was inhaled as well as its concentration and the duration of exposure. No lung changes such as he describes were observed in the present series, and there is no evidence of persistent intoxication. The presence of acid burns on the skin appeared to have no relation to the amount of antimony found in the urine.

\section{REFERENCES}

Brieger, H., Semisch, C. W., Stasney, J., and Piatnek, D. A. (1954). Industr. Med. Surg., 23, 521.

Browning, Ethel (1961). Toxicity of Industrial Metals. Butterworths, London.

Gallina, R., and Luvoni, R. (1958). Rass. Med. industr., 27, 28.

Manufacturing Chemists Association (1957). Chemical Safety Data Sheet SD 66. Antimony Trichloride. Washington.

McCallum, R. I. (1963). Ann. occup. Hyg., 6, 55.

Renes, L. E. (1953). Arch. industr. Hyg., 7, 99. 